\title{
Expenditures for innovations and foreign direct investments in Bulgaria - regional aspects, features and trends
}

\author{
Mariana Petrova*, and Sergey Radukanov \\ St. Cyril and St. Methodius University of Veliko Tarnovo, T. Tarnovsky 2, Veliko Tarnovo, 5003, Bulgaria
}

\begin{abstract}
The study examines the costs of innovation and foreign direct investment by district (NUTS 3), Planning regions (NUTS 2) and Regions (NUTS 1), according to the classification of territorial units for statistical purposes. The main trends in their development are outlined. The authors believe that foreign direct investment is closely linked to the cost of innovation. Of particular importance is the view that the intensity of R\&D expenditure by statistical regions and districts almost coincides with foreign direct investment. The results of the analysis confirm the strong disproportion in recent years in the distribution of direct investment and R\&D expenditures, which leads to the formation of a highly developed center Sofia district (capital) and weak periphery - all other districts.
\end{abstract}

\section{Introduction}

In the context of European vector development and harmonious entry into the global economy, the Bulgarian economy has the task of ensuring international competitiveness, and the main channel for the transfer of innovation is foreign direct investment. The latter are the driver of economic growth and have an impact through the formation and accumulation of new capital and technological renewal.

Therefore, the study of research and development costs and foreign direct investment at the regional level is particularly relevant. The current development focuses on the costs of innovation in the context of foreign direct investment, and the subject - the dynamics of their development in the regional aspect.

The goal is to analyze the level and outline the trends on a regional scale. In order to achieve the formulated goal, it is necessary to solve the following tasks:

- analysis of the dynamics of foreign direct investments in the regional aspect;

- study of the dynamics of expenditures for research and development by statistical regions.

\section{Theoretical background}

The notion of innovation was put under analysis already in the middle of the previous century, J.A. Schumpeter defined innovation as [1]:

- introduction of a new product,

- introduction of a new production method (process innovation),

- opening of a new sales market,

- opening of a new supply market,

- introduction of a new organisation.
E.M. Rogers [2] defines innovation differently, relying on the assumption that it encompasses any concept, idea, relation, position or object that stands out among all previously existing due to its quality.

Peter F. Drucker formulated innovation as "the specific tool of entrepreneurs, the means by which they exploit change as an opportunity for a different business or a different service".

D. Cavagnoli defines innovation as the process of creative use of knowledge, transformation of knowledge owned by an organization or acquired from outside, to be used in new products, services or processes [3].

The opinions presented (positions) are just a few of the countless definitions formulated by a large group of scientists who have dealt with this issue. In this field we can distinguish part of the research of Pukala [4, 5], Pukala \& Linde [6], Bacho et al. [7], Seitzhanov et al. [8], Adamišin et al. [9], Labunska et al. [10], Sushchenko \& Trunina [11], whose multi-layered analysis of innovation has enriched and expanded knowledge in this area.

Scientists dealing with innovation in a global sense have developed a standard definition, which has been published by the EC under the title "The Oslo Manual" [12]. It represents a point of reference for the majority of studies on innovation. According to a definition contained therein, innovation is "the implementation of a new or significantly improved product (good or service), or process, a new marketing method, or a new organizational method in business practices, workplace organization or external relations". The problem of organizing efficient innovation activity invoked great scientific interests of Bulgarian and Latvian researchers, such as Komarova V., Selivanova-Fyodorova N., Ruza O., Kaźmierczyk J., Arbidane [13], Zahariev, Zveryakov, Prodanov, Zaharieva, Angelov, Zarkova, 
Petrova [14] Deneva \& Grasis [15], Tepavicharova, Aleksejeva \& Vazov [16], Tepavicharova \& Zahars [17].

\section{Materials and methods}

At the first stage of the study, it seems appropriate to use methods of collecting, systematizing and analyzing literary sources.

Further, the official statistics of the National statistical institute of the Republic of Bulgaria should be used, since they will help characterize the current state of innovative activities in Bulgaria.

To identify differences in the development of the main elements of the national innovation system, it is advisable to use the method of comparison.

All results refer to relevant sources of information of the National statistical institute of the Republic of Bulgaria or are based on authors' own calculations.

\section{Results and discussion}

All the conclusions of the authors are based solely on the results of their own calculations, based on generally recognized ratings with a transparent methodology and a wide list of indicators ensuring their objectivity and published from National statistical institute of the Republic of Bulgaria.

The volume of foreign direct investment (FDI) attracted in the country is 21581579.6 thousand euros for 2014 and reaches a level of 24919589.3 thousand euros for 2018 (Fig. 1).

The data show that for the period from 2014 to 2018 , foreign direct investment is growing. For the considered period in absolute terms the increase is by +3338009.7 thousand BGN, and in relative aspect it is $15.47 \%$. The growth rate indicator compared to the previous period has the highest value for 2015 compared to 2014. - (+7, $33 \%)$.

FDI in Bulgaria for the period of 2014-2018 (in thousands of EUR)

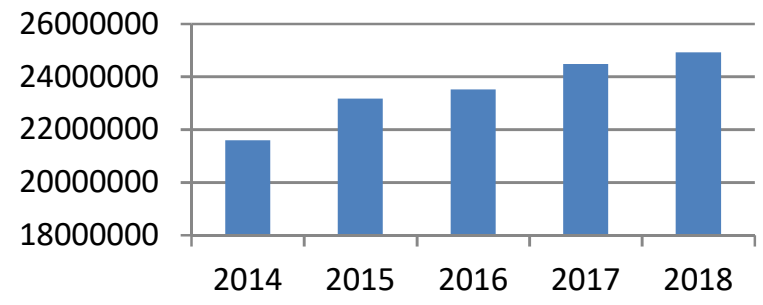

Fig 1. Foreign direct investment in Bulgaria for the period of 2014-2018 (in thousands of EUR)

For other periods it is characterized by lower values: $2016 / 2015$ is $+1.49 \%, 2017 / 2016-(+4.11 \%)$ and for $2018 / 2017-(+1.82 \%)$. For the whole period there is a steady upward trend in foreign direct investment. The average annual growth rate is $+3.69 \%$. The development of the gross domestic product in Bulgaria Mitkov [18].

For research and analysis of FDI at the regional level (see Table 1), the average value of foreign direct investment for the country is calculated by areas:

\section{FDI (total for the country)/28 (districts count)}

The obtained arithmetic average value shows the inflow of FDI of one conditional, statistically average area in Bulgaria.

Table 1. FDI in Bulgaria, by districts (NUTS 3) and average for the country for the period of $2014-2018$ (in thous. of

\begin{tabular}{|c|c|c|c|c|c|}
\hline \multicolumn{6}{|c|}{ EUR) } \\
\hline Regions & 2014 & 2015 & 2016 & 2017 & 2018 \\
\hline Vidin & 51686 & 77842 & 71466 & 73043 & 80909 \\
\hline Vratsa & 138052 & 85677 & 76903 & 108893 & 106294 \\
\hline Lovech & 134000 & 147443 & 139150 & 114073 & 120982 \\
\hline Montana & 34218 & 27355 & 36978 & 38191 & 35542 \\
\hline Pleven & 306765 & 282479 & 187588 & 226473 & 125995 \\
\hline VelikoTarnovo & 108176 & 121708 & 147375 & 134034 & 140662 \\
\hline Gabrovo & 265205 & 284368 & 302616 & 326309 & 338201 \\
\hline Razgrad & 114509 & 104855 & 131300 & 152460 & 175490 \\
\hline Rousse & 385755 & 337023 & 367855 & 374815 & 429190 \\
\hline Silistra & 31667 & 28803 & 32685 & 36013 & 28115 \\
\hline Varna & 1679193 & 1760957 & 1785198 & 1946023 & 1869908 \\
\hline Dobrich & 111566 & 202894 & 244206 & 270243 & 311763 \\
\hline Targovishte & 198286 & 204744 & 227261 & 244815 & 280506 \\
\hline Shumen & 104871 & 103320 & 103093 & 107798 & 117305 \\
\hline Bourgas & 937227 & 1704392 & 1746015 & 1887318 & 2059421 \\
\hline Sliven & 92702 & 90252 & 124199 & 139289 & 161505 \\
\hline Stara Zagora & 969271 & 1023382 & 920971 & 905946 & 929285 \\
\hline Yambol & 58091 & 79030 & 56527 & 50680 & 52899 \\
\hline Blagoevgrad & 384666 & 446364 & 482987 & 474397 & 499327 \\
\hline Kyustendil & 43524 & 42028 & 43720 & 42782 & 42946 \\
\hline Pernik & 218999 & 178902 & 186558 & 204136 & 199062 \\
\hline Sofia district & 1239078 & 1274063 & 1313943 & 1464101 & 1389012 \\
\hline Sofia city & 11675227 & 12111790 & 12211562 & 12310741 & 12432131 \\
\hline Kardzhali & 143951 & 176317 & 153124 & 256162 & 291633 \\
\hline Pazardzhik & 472035 & 486357 & 480425 & 505856 & 516146 \\
\hline Plovdiv & 1546360 & 1592531 & 1731002 & 1895015 & 1911939 \\
\hline Smolyan & 75175 & 83064 & 83761 & 82920 & \begin{tabular}{|l|}
90632,8 \\
\end{tabular} \\
\hline Haskovo & 61324 & 105335 & 120400 & 102671 & 182793 \\
\hline $\begin{array}{l}\text { National } \\
\text { Total }\end{array}$ & 21581579 & 23163273 & 23508865 & 24475196 & 24919589 \\
\hline $\begin{array}{l}\text { National } \\
\text { average }\end{array}$ & 770771 & 827260 & 839602 & 874114 & 889985 \\
\hline
\end{tabular}

Source: own calculations based on NSI (2018).

The value obtained is compared with foreign direct investment in specific areas for all years.

The study logically presents the comparison between the national average with the specific indicator by district. 
Table 2. Comparison of the FDI in Bulgaria by districts with the national average for the period of $2014-2018$

\begin{tabular}{|c|c|c|}
\hline$\stackrel{\nwarrow}{\S}$ & $\begin{array}{c}\text { Districts with } \\
\text { FDI above the } \\
\text { national } \\
\text { average }\end{array}$ & $\begin{array}{c}\text { Districts with FDI } \\
\text { below the national average }\end{array}$ \\
\hline 2014 & $\begin{array}{l}6 \text { regions - } \\
\text { Sofiacity, } \\
\text { Varna, } \\
\text { Plovdiv, Sofia, } \\
\text { Stara } \\
\text { Zagora,Bourgas }\end{array}$ & $\begin{array}{l}22 \text { regions - Pazardzhik, } \\
\text { Rousse, Blagoevgrad, } \\
\text { Pleven, Gabrovo, Pernik, } \\
\text { Targovishte, Kardzhali, } \\
\text { Vratsa, Lovech, Razgrad, } \\
\text { Dobrich, VelikoTarnovo, } \\
\text { Shumen, Sliven, Smolyan, } \\
\text { Haskovo, Yambol, Vidin, } \\
\text { Kyustendil, Montana, } \\
\text { Silistra }\end{array}$ \\
\hline 2015 & $\begin{array}{l}6 \text { regions - } \\
\text { Sofiacity,Varna, } \\
\text { Bourgas, } \\
\text { Plovdiv, Sofia, } \\
\text { Stara Zagora }\end{array}$ & $\begin{array}{l}22 \text { regions - Pazardzhik, } \\
\text { Blagoevgrad, Rousse, } \\
\text { Gabrovo, Pleven, } \\
\text { Targovishte, Dobrich, } \\
\text { Pernik, Kardzhali, Lovech, } \\
\text { VelikoTarnovo, Haskovo, } \\
\text { Razgrad, Shumen, Sliven, } \\
\text { Vratsa, Smolyan, Yambol, } \\
\text { Vidin, Kyustendil, Silistra, } \\
\text { Montana }\end{array}$ \\
\hline 2016 & $\begin{array}{l}6 \text { regions - } \\
\text { Sofiacity, } \\
\text { Varna, Bourgas, } \\
\text { Plovdiv, Sofia, } \\
\text { Stara Zagora }\end{array}$ & $\begin{array}{l}22 \text { regions - Blagoevgrad, } \\
\text { Pazardzhik, Rousse, } \\
\text { Gabrovo, Dobrich, } \\
\text { Targovishte, Pleven, } \\
\text { Pernik, Kardzhali, Veliko } \\
\text { Tarnovo, Lovech, Razgrad, } \\
\text { Sliven, Haskovo, Shumen, } \\
\text { Smolyan, Vratsa, Vidin, } \\
\text { Yambol, Kyustendil, } \\
\text { Montana, Silistra }\end{array}$ \\
\hline 2017 & $\begin{array}{l}6 \text { regions - } \\
\text { Sofia city, } \\
\text { Varna, Plovdiv, } \\
\text { Bourgas, Sofia, } \\
\text { Stara Zagora }\end{array}$ & $\begin{array}{l}22 \text { regions - Pazardzhik, } \\
\text { Blagoevgrad, Rousse, } \\
\text { Gabrovo, Dobrich, } \\
\text { Kardzhali, Targovishte, } \\
\text { Pleven, Pernik, Razgrad, } \\
\text { Sliven, Veliko Tarnovo, } \\
\text { Lovech, Vratsa, Shumen, } \\
\text { Haskovo, Smolyan, Vidin, } \\
\text { Yambol, Kyustendil, } \\
\text { Montana, Silistra }\end{array}$ \\
\hline 2018 & $\begin{array}{l}6 \text { regions - } \\
\text { Sofiacity, } \\
\text { Bourgas, } \\
\text { Plovdiv, Varna, } \\
\text { Sofia, Stara } \\
\text { Zagora }\end{array}$ & $\begin{array}{l}22 \text { regions-Pazardzhik, } \\
\text { Blagoevgrad, Rousse, } \\
\text { Gabrovo, Dobrich, } \\
\text { Kardzhali, Targovishte, } \\
\text { Pernik, Haskovo, Razgrad, } \\
\text { Sliven, Veliko Tarnovo, } \\
\text { Pleven, Lovech, Shumen, } \\
\text { Vratsa, Smolyan, Vidin, } \\
\text { Yambol, Kyustendil, } \\
\text { Montana, Silistra }\end{array}$ \\
\hline
\end{tabular}

Source: authors' calculation

The analysis for the period of 2014-2018 confirms that the number of territorial units in the two separate groups is unchanged - a separate group of six districts has foreign direct investment above the national average and for the rest (the same during the study period) twenty and two, the values are lower than the national average.

The leading place in attracting foreign direct investment is occupied by Sofia city (capital). According to the territorial-administrative division of Bulgaria, there are two districts with similar names, but it is important to distinguish them. One is Sofia city (capital), and the other is Sofia district The strong concentration is understandable, as in addition to the large population, it is the administrative center of Bulgaria and as such is an attractive place for localization of foreign companies and representative offices. For the considered period the dominant role is also played by the district of Varna, which for the last year gives way to the second place to the districts of Burgas and Plovdiv.

In the group of districts with foreign direct investment below the national average, the district of Pazardzhik has a dominant role. It is explained by the proximity to Plovdiv and the related productions in a number of areas. The districts of Blagoevgrad and Ruse are directly below the district of Pazardzhik, excluding the result in 2016. For the period of the study, the districts with the lowest values remain the same: Vidin, Yambol, Kyustendil, Montana and Silistra.

According to the Global Innovation Index [19], in 2020 Bulgaria ranks 37th, and for the previous year it ranked 40th. With reasonable optimism, we can determine a relatively positive trend and restore the 37 th position from 2018.

In order to study innovations according to the classification of territorial units, the latter must be presented in the aggregate form - by NUTS 2 planning regions.

Table 3. Expenditures for research and development by NUTS 2 planning regions for the period of $2014-2018$ (in thous. of BGN)

\begin{tabular}{|l|r|r|r|r|r|}
\hline Planning regions & $\mathbf{2 0 1 4}$ & $\mathbf{2 0 1 5}$ & $\mathbf{2 0 1 6}$ & $\mathbf{2 0 1 7}$ & $\mathbf{2 0 1 8}$ \\
\hline Northwestern & 11900 & 33265 & 29752 & 31285 & 37437 \\
\hline Northern Central & 10661 & 37218 & 30654 & 30226 & 26612 \\
\hline Northeastern & 33763 & 35566 & 51545 & 51626 & 49750 \\
\hline Southeastern & 27459 & 36415 & 33892 & 39094 & 42137 \\
\hline Southwestern & 550827 & 642876 & 522683 & 538651 & 603853 \\
\hline Southern Central & 30219 & 65117 & 65748 & 69352 & 69115 \\
\hline National Total & 664829 & 850457 & 734274 & 760234 & 828904 \\
\hline
\end{tabular}

Note - the table is compiled according to the NSI [19]

For the researched 5-year period the expenses for innovations increased by 164075 thousand $\mathrm{BGN}$ or by $24.68 \%$. The average annual growth rate is $6.71 \%$. The Southwest region has the greatest weight - the costs for innovation are significant. Structurally, its share varies between $82 \%$ and $73 \%$. It is understandable because it includes Sofia district and Sofia district (capital). The least represented are the regions Northwest and North Central. 
The disproportion between the different regions stands out to a greater extent if the same data are considered, but in aggregate form - by zones, NUTS 1 level (see Table 4).

Table 4. Expenditures for research and development by NUTS 1 regions

\begin{tabular}{|l|r|r|r|r|r|}
\hline Regions & 2014 & 2015 & 2016 & 2017 & 2018 \\
\hline $\begin{array}{l}\text { Northern and } \\
\text { Eastern Bulgaria }\end{array}$ & 83783 & 142464 & 145843 & 152231 & 155936 \\
\hline $\begin{array}{l}\text { South-Western and } \\
\text { South-Central } \\
\text { Bulgaria }\end{array}$ & 581046 & 707993 & 588431 & 608003 & 672968 \\
\hline National Total & 664829 & 850457 & 734274 & 760234 & 828904 \\
\hline
\end{tabular}

Note - the table is compiled according to the NSI [20]
The relative share of expenditures for research activities in Northern and Southeastern Bulgaria is insignificant - in 2017 it was $20.02 \%$, when it registered a peak, and the lowest value was registered in 2014 with only $12.60 \%$.

Tracking the relative share of expenditures for research and development by districts in relation to the gross domestic product by districts for the studied period is of interest and shows surprising results (Table 5).

Table 5. Expenditure for R\&D related to GDP (by district), decremental order

\begin{tabular}{|c|c|c|c|c|c|c|c|c|c|c|}
\hline & District & 2014 & District & 2015 & District & 2016 & District & 2017 & District & 2018 \\
\hline 1 & Sofiacity & $1.64 \%$ & Sofiacity & $1.74 \%$ & Lovech & $1.34 \%$ & Shumen & $1.40 \%$ & Sofiacity & $1.32 \%$ \\
\hline 2 & Varna & $0.50 \%$ & Lovech & $1.38 \%$ & Sofiacity & $1.32 \%$ & Sofiacity & $1.28 \%$ & Lovech & $1.26 \%$ \\
\hline 3 & Pazardzhik & $0.48 \%$ & Pazardzhik & $0.80 \%$ & Shumen & $0.96 \%$ & Lovech & $1.08 \%$ & Shumen & $1.13 \%$ \\
\hline 4 & Lovech & $0.43 \%$ & Pleven & $0.76 \%$ & Pazardzhik & $0.73 \%$ & Pazardzhik & $0.84 \%$ & Pleven & $0.81 \%$ \\
\hline 5 & Stara Zagora & $0.40 \%$ & Rousse & $0.72 \%$ & Rousse & $0.68 \%$ & Pleven & $0.72 \%$ & Plovdiv & $0.58 \%$ \\
\hline 6 & Pleven & $0.35 \%$ & Plovdiv & $0.66 \%$ & Plovdiv & $0.61 \%$ & Plovdiv & $0.56 \%$ & Pazardzhik & $0.57 \%$ \\
\hline 7 & Plovdiv & $0.33 \%$ & Yambol & $0.53 \%$ & Varna & $0.56 \%$ & Rousse & $0.55 \%$ & Rousse & $0.49 \%$ \\
\hline 8 & Yambol & $0.31 \%$ & Sofia & $0.51 \%$ & Pleven & $0.53 \%$ & Gabrovo & $0.51 \%$ & Stara Zagora & $0.45 \%$ \\
\hline 9 & Rousse & $0.28 \%$ & Varna & $0.47 \%$ & Stara Zagora & $0.35 \%$ & Varna & $0.40 \%$ & Gabrovo & $0.44 \%$ \\
\hline 10 & Sofia & $0.26 \%$ & Stara Zagora & $0.44 \%$ & Gabrovo & $0.34 \%$ & Stara Zagora & $0.33 \%$ & Yambol & $0.42 \%$ \\
\hline 11 & Shumen & $0.19 \%$ & Sliven & $0.38 \%$ & Yambol & $0.34 \%$ & $\begin{array}{l}\text { Veliko } \\
\text { Tarnovo }\end{array}$ & $0.32 \%$ & Varna & $0.36 \%$ \\
\hline 12 & Bourgas & $0.14 \%$ & Shumen & $0.32 \%$ & $\begin{array}{l}\text { Veliko } \\
\text { Tarnovo }\end{array}$ & $0.33 \%$ & Sofia & $0.26 \%$ & Sliven & $0.34 \%$ \\
\hline 13 & Blagoevgrad & $0.14 \%$ & Vratsa & $0.24 \%$ & Sofia & $0.31 \%$ & Dobrich & $0.21 \%$ & Dobrich & $0.30 \%$ \\
\hline 14 & $\begin{array}{l}\text { Veliko } \\
\text { Tarnovo }\end{array}$ & $0.12 \%$ & $\begin{array}{l}\text { Veliko } \\
\text { Tarnovo }\end{array}$ & $0.22 \%$ & Kardzhali & $0.31 \%$ & Blagoevgrad & $0.17 \%$ & Kyustendil & $0.28 \%$ \\
\hline 15 & Gabrovo & $0.10 \%$ & Bourgas & $0.17 \%$ & Sliven & $0.29 \%$ & Bourgas & $0.16 \%$ & Sofia & $0.25 \%$ \\
\hline 16 & Kyustendil & $0.08 \%$ & Blagoevgrad & $0.16 \%$ & Blagoevgrad & $0.21 \%$ & Montana & $0.15 \%$ & $\begin{array}{l}\text { Veliko } \\
\text { Tarnovo }\end{array}$ & $0.20 \%$ \\
\hline 17 & Vratsa & $0.04 \%$ & Smolyan & $0.16 \%$ & Vidin & $0.18 \%$ & Vratsa & $0.12 \%$ & Blagoevgrad & $0.16 \%$ \\
\hline 18 & Sliven & $0.04 \%$ & Montana & $0.09 \%$ & Bourgas & $0.18 \%$ & Haskovo & $0.08 \%$ & Bourgas & $0.15 \%$ \\
\hline 19 & Haskovo & $0.04 \%$ & Silistra & $0.09 \%$ & Montana & $0.16 \%$ & Vidin & $0.07 \%$ & Montana & $0.12 \%$ \\
\hline 20 & Pernik & $0.02 \%$ & Vidin & $0.08 \%$ & Smolyan & $0.13 \%$ & Targovishte & $0.02 \%$ & Vratsa & $0.11 \%$ \\
\hline 21 & Vidin & $\mathrm{n} / \mathrm{a}$ & Gabrovo & $\mathrm{n} / \mathrm{a}$ & Vratsa & $0.12 \%$ & Razgrad & $\mathrm{n} / \mathrm{a}$ & Vidin & $0.10 \%$ \\
\hline 22 & Montana & $\mathrm{n} / \mathrm{a}$ & Razgrad & $\mathrm{n} / \mathrm{a}$ & Haskovo & $0.04 \%$ & Silistra & $\mathrm{n} / \mathrm{a}$ & Haskovo & $0.10 \%$ \\
\hline 23 & Razgrad & $\mathrm{n} / \mathrm{a}$ & Dobrich & $\mathrm{n} / \mathrm{a}$ & Razgrad & $\mathrm{n} / \mathrm{a}$ & Sliven & $\mathrm{n} / \mathrm{a}$ & Pernik & $0.08 \%$ \\
\hline 24 & Silistra & $\mathrm{n} / \mathrm{a}$ & Targovishte & $\mathrm{n} / \mathrm{a}$ & Silistra & $\mathrm{n} / \mathrm{a}$ & Yambol & $\mathrm{n} / \mathrm{a}$ & Targovishte & $0.02 \%$ \\
\hline 25 & Dobrich & $\mathrm{n} / \mathrm{a}$ & Kyustendil & $\mathrm{n} / \mathrm{a}$ & Dobrich & $\mathrm{n} / \mathrm{a}$ & Kyustendil & $\mathrm{n} / \mathrm{a}$ & Razgrad & $\mathrm{n} / \mathrm{a}$ \\
\hline 26 & Targovishte & $\mathrm{n} / \mathrm{a}$ & Pernik & $\mathrm{n} / \mathrm{a}$ & Targovishte & $\mathrm{n} / \mathrm{a}$ & Pernik & $\mathrm{n} / \mathrm{a}$ & Silistra & $\mathrm{n} / \mathrm{a}$ \\
\hline 27 & Kardzhali & $\mathrm{n} / \mathrm{a}$ & Kardzhali & $\mathrm{n} / \mathrm{a}$ & Kyustendil & $\mathrm{n} / \mathrm{a}$ & Kardzhali & $\mathrm{n} / \mathrm{a}$ & Kardzhali & $\mathrm{n} / \mathrm{a}$ \\
\hline 28 & Smolyan & $\mathrm{n} / \mathrm{a}$ & Haskovo & $\mathrm{n} / \mathrm{a}$ & Pernik & $\mathrm{n} / \mathrm{a}$ & Smolyan & $\mathrm{n} / \mathrm{a}$ & Smolyan & $\mathrm{n} / \mathrm{a}$ \\
\hline
\end{tabular}

For certain years by districts, the NSI classifies data on research and development as confidential. In practice, the relative share of $R \& D$ expenditure in relation to GDP by district cannot be calculated due to a lack of official data.
It is indisputable and explainable that Sofia district (capital) dominates in all years with the highest relative share. Impressive are 2016 and 2017, when Sofia capital gave away the leading position to the districts of Lovech and Shumen, respectively. The latter are established as leaders for the period 2014-2018. 
The districts of Vidin, Montana, Vratsa, Silistra and Targovishte stand out with an extremely low relative share for the studied period. This is not surprising; these areas are traditionally positioned in the last places and in a number of other areas - social, demographic and economic indicators.

\section{Conclusions}

The limitations of the scientific study that the study was conducted exclusively on statistical data.

The study allows us to make the following conclusions:

- there is an asymmetric distribution of foreign direct investment and research and development expenditure by districts and statistical regions;

- the intensity of research and development expenditures by statistical regions almost coincides with foreign direct investment. This means that there is a direct correlation between foreign direct investment and $\mathrm{R} \& \mathrm{D}$ expenditure;

- $\quad$ the largest amount of foreign direct investment and expenditures for research and development is the Southwest region, and with the lowest values are North Central and Northwest;

- the strong disproportion in the distribution of direct investments and the costs for research and development activity leads to the establishment in this respect of a highly developed center - Sofia district (capital) and weak periphery - all other districts.

\section{References}

1. J.A. Schumpeter. The Theory of Economic Development. An Inquiry into Profits, Capital, Credit, Interest, and the Business Cycle. (Cambridge, MAUS: Harvard University Press, 1934).

2. E.M. Rogers. Diffusion of innovations (Free Press, New York, 2003)

3. D. Cavagnoli, Innovation: Management, Policy and Practice, 13, 4 (2011)

4. R. Pukala, Economics and Management, 8:3, 1 (2016)

5. R. Pukala, MATEC Web Conf., 297, 08002 (2019)

6. R Pukala, I. Linde. E3S Conf., 174, 04030 (2020)

7. R. Bacho, R. Pukala, S. Hlibko, N. Vnukova, P. Pola. Marketing and Management of Innovations, 3, 297-307. (2019).

8. S. Seitzhanov, N. Kurmanov, M. Petrova, U. Aliyev, N. Aidargaliyeva, Entrepreneurship and Sustainability Issues, 7:4, 2615-2629 (2020)

9. P. Adamišin, R. Vavrek, R. Pukala. SGEM conf, 3(5), 135-140.

10. Sv. Labunska, M. Petrova, O. Prokopishyna, Economic Annals - XXI, 165:5-6, 3-18 (2017)

11. O. Sushchenko, I. Trunina, Actual Problems of Economics, 177:3, 191-198 (2016)

12. The measurement of scientific and technological activities. Proposed guidelines for collecting and interpreting technological innovation data. OSLO Manual.

13. Komarova V., Selivanova-Fyodorova N., Ruza O., Kaźmierczyk J., Arbidane I. (2021). Entrepreneurship and Sustainability Issues 8(3): 110-121.

14. Laktionova, O., Dobrovolskyi, O., Karpova, T. S., \& Zahariev, A. Management Theory and Studies for Rural Business and Infrastructure Development, 41(1), 62-73. (2019).

15. A. Deneva, J. Grasis. E3S Conf., 174, 01026. (2020).

16. M. Tepavicharova, L. Aleksejeva, R. Vazov. E3S Web of Conf., 174, art. no. 04031. (2020).

17. M. Tepavicharova, L. Dikova, V. Zahars. E3S Web of Conf., 105, 04029, (2019)

18. M. Mitkov. Social and Economic Analysis, 10(1), 34-44 (2018).

19. Global Innovation Index 2020: Who Will Finance Innovation? Retrieved from: ttps://www.globalinnovationindex.org/

20. INFOSTAT information system Retrieved from: https://infostat.nsi.bg/

21. Global Innovation Index 2019 rankings, Retrieved from:https://www.wipo.int/edocs/pubdocs/en/wipo _pub_gii_2019-intro4.pdf

22. Global Innovation Index 2018 rankings, Retrieved from:https://www.wipo.int/edocs/pubdocs/en/wipo _pub_gii_2018-intro5.pdf 